\title{
The Current State of Clinical Trials Studying Hydrocephalus: An Analysis of ClinicalTrials.gov
}

Mickey E. Abraham ${ }^{1}$, Roman Povolotskiy ${ }^{2}$, Justin Gold ${ }^{2}$, Max Ward ${ }^{2}$, Julian L. Gendreau ${ }^{3}$, Antonios Mammis ${ }^{2}$

1. Department of Neurosurgery, University of California, San Diego, USA 2. Department of Neurosurgery, Rutgers New Jersey Medical School, Newark, USA 3. Graduate Medical Education, Eisenhower Army Medical Center, Fort Gordon, Augusta, USA

Corresponding author: Julian L. Gendreau, juliangendreau@gmail.com

\section{Abstract \\ Introduction}

Hydrocephalus is a significant public health concern estimated to affect 380,000 new individuals annually. In addition, it exhibits an increasingly high financial burden for the healthcare industry. Clinical trials are the gold standard for evaluating preventative and therapeutic strategies to bring potential treatments to the forefront of clinical practice.

\section{Methods}

A study of the ClinicalTrials.gov was conducted in April 2019 to examine all current and previously reported clinical trials studying hydrocephalus. Studies were reviewed to extrapolate information to characterize the current state of research being conducted for hydrocephalus.

\section{Results}

In total, 80 clinical trials met inclusion criteria and were analyzed: $48.8 \%$ were observation and $51.2 \%$ were interventional. Of those, $55 \%$ have been completed while $30.0 \%$ are still recruiting, and $15.0 \%$ are not yet recruiting. The United States has the most clinical trials (42.0\%) and a plurality of trials has a sample size of 0-50 participants. The majority of studies included only adults (53.8\%). Of those studies, $54.0 \%$ were cohort and the majority were prospective (74.0\%). Of the different types of hydrocephalus, normal pressure hydrocephalus and pediatric hydrocephalus have generated the most interest for research comprising a majority of the clinical trial registry. While 44 of the trials are complete, only 20 have published results in peer-reviewed literature highlighting the need for improvement in publishing study results even if the results of the trials are null.

\section{Conclusion}

Received 08/11/2020

Review began 08/12/2020 Review ended 08/17/2020 Published 08/25/2020

\section{() Copyright 2020}

Abraham et al. This is an open access article distributed under the terms of the Creative Commons Attribution License CC-BY 4.0., which permits unrestricted use, distribution, and reproduction in any medium, provided the original author and source are credited.
Most clinical trials to date have pertained to the treatment of normal pressure hydrocephalus and pediatric hydrocephalus. While great advancements have been made for the treatment of hydrocephalus, there remains much room for improvements in therapeutic interventional modalities as well as ensuring the reporting of all undertaken clinical trials.

\section{Categories: Neurosurgery}

Keywords: review of clinical trials, post-hemorrhagic hydrocephalus, pediatric hydrocephalus, normal pressure hydrocephalus, hydrocephalus

\section{Introduction}

Hydrocephalus, first described by Hippocrates as early as the fifth century BCE, is an abnormal accumulation of cerebrospinal fluid (CSF) within the ventricles of the brain either due to insufficient CSF reabsorption or CSF overproduction [1]. It is a significant public health concern estimated to affect 380,000 new individuals annually [2]. As a result, CSF diversion procedures such as ventriculoperitoneal shunting (VPS) and endoscopic third ventriculostomy (ETV) accrue a total cost of $\$ 2$ billion nationwide [3]. One study suggests that treating hydrocephalus in the elderly, has the potential to lower five-year Medicare expenditures by approximately $\$ 184.3$ million in the United States [4].

Hydrocephalus can develop for a variety of reasons. Obstructive, or noncommunicating, hydrocephalus occurs when CSF does not flow properly between ventricles or out of the ventricles due to an obstruction. This obstruction can be the result of congenital malformations or ventricular narrowing due to other pathologies such as cancer or trauma [5]. Nonobstructive, or communicating, hydrocephalus occurs when CSF flows out of the ventricles and into the spinal canal, but the tissue surrounding the brain and spinal cord is unable to reabsorb it adequately enough to prevent excess accumulation of the fluid [6]. 
Major types of hydrocephalus include congenital hydrocephalus, acquired hydrocephalus, and normal pressure hydrocephalus (NPH) [7].

In 2012, researchers from across the globe convened at the symposium, "Opportunities in Hydrocephalus Research: Pathways to Better Outcomes," ultimately recommending four areas of hydrocephalus research to most efficiently improve patient care [8]. These include: discovering genetic and pathophysiologic causes of the diagnosis, developing improved biomarkers for diagnosis, discovering new bioengineering and surgical advances for treatment, and also enhancing neuropsychological and quality of life initiatives. These comprehensive recommendations accentuate most of the ongoing research of hydrocephalus and have the potential to refine diagnoses, improve clinical outcomes, and reduce healthcare expenditure $[9,10]$.

Clinical trials remain the gold standard for evaluating novel diagnostic, preventative, and therapeutic strategies before it reaches the forefront of clinical practice [11]. Therefore, the present study examined a major worldwide registry, ClinicalTrials.gov, for all trials involving hydrocephalus. This analysis identified and characterized the current state of clinical trials focused on hydrocephalus. This analysis attempts to understand what steps have already been taken, and what areas of research remain to be explored in order to continue improving the management of hydrocephalus.

\section{Materials And Methods}

ClinicalTrials.gov is a public trial registry provided by the United States National Library of Medicine and the United States Food and Drug Administration that contains over 301,795 research studies conducted in 208 countries and all 50 states. The authors conducted a search on April 8, 2019 to examine all current clinical trials studying hydrocephalus.

The trials were obtained from the ClinicalTrials.gov website using the advanced search function for the search term "hydrocephalus" under "condition." Of those identified by this search criteria, clinical trials were excluded from the analysis if they were suspended, terminated, withdrawn, or had unknown status. For the trials that met inclusion criteria, the following information was used in the final analysis: registered identifier number, official title, recruitment status, study type, primary purpose, year of initiation, intervention, country, study type, sample size, year of initiation, year of completion, time perspective, primary purpose, intervention, participant age, country of origin, and primary outcome. In addition, an effort was made to retrieve the results of completed trials for further analysis. For all completed trials, an online Medline database search for published results was conducted on May 2, 2019, using each clinical trial's registered identifier number. Descriptive statistics were used to analyze the variables.

\section{Results}

In total, 123 trials were identified. Of these identified, 43 trials were excluded from the analysis due to suspended, terminated, withdrawn, or unknown status. The remaining 80 studies were included in this study. A complete list of included studies can be found in Appendix 1.

Among the 80 eligible trials, 39 (48.8\%) were observational and 41 were interventional (51.2\%). The trials took place from 1992 to 2019, with 43 (53.8\%) studies beginning after 2013. Therefore, there appears to be an increasing trend of clinical trials since 1992 (Figure 1). The majority of trials, 44 (55.0\%), have been completed, 24 (30.0\%) are still recruiting, and the remaining 12 (15.0\%) are not yet recruiting. Of the 44 completed trials, the average time to completion was 50 months.

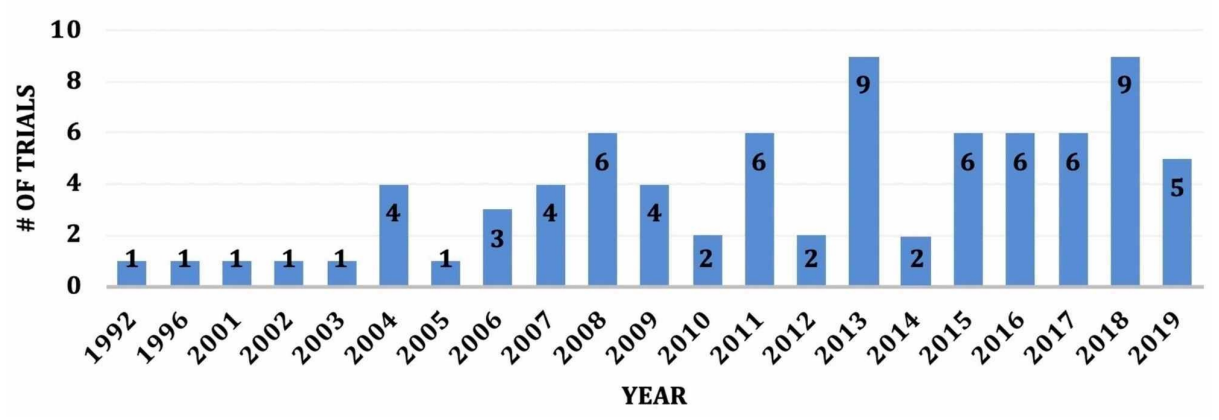

FIGURE 1: Number of Clinical Trials Beginning Stratified by Year

The United States of America has the most clinical trials, 45 (42.0\%), with the rest originating in predominantly westernized or European countries (Table 1). Enrollment in these trials included a wide range: 30 (37.5\%) trials had a sample size of 0-50, 21 (26.3\%) had a sample size of 50-100, 25 (31.3\%) had a sample size of 101-500, and 4 (5.0\%) had an enrollment that exceeded 501. The median number of 


\section{Cureus}

participants was 158 among all trials. When stratified by participant age, 43 (53.8\%) included only adults (18 years and older), 18 (22.5\%) included only children (aged 0-18 years), and 19 (23.8\%) included all ages.

\begin{tabular}{|c|c|c|}
\hline Country & $\mathbf{N}$ & $\%$ \\
\hline Austria & 1 & $1.3 \%$ \\
\hline China & 3 & $3.8 \%$ \\
\hline Denmark & 1 & $1.3 \%$ \\
\hline France & 6 & $7.5 \%$ \\
\hline Germany & 3 & $3.8 \%$ \\
\hline Israel & 2 & $2.5 \%$ \\
\hline Japan & 1 & $1.3 \%$ \\
\hline Malaysia & 1 & $1.3 \%$ \\
\hline Netherlands & 1 & $1.3 \%$ \\
\hline Spain & 1 & $1.3 \%$ \\
\hline Sweden & 5 & $6.3 \%$ \\
\hline Switzerland & 4 & $5.0 \%$ \\
\hline Turkey & 1 & $1.3 \%$ \\
\hline Uganda & 1 & $1.3 \%$ \\
\hline United Kingdom & 1 & $1.3 \%$ \\
\hline USA & 37 & $46.3 \%$ \\
\hline Multiple Countries & 10 & $12.5 \%$ \\
\hline $\mathrm{N} / \mathrm{A}$ & 1 & $1.3 \%$ \\
\hline
\end{tabular}

\section{TABLE 1: Nationality of Registered Clinical Trials for Hydrocephalus}

Of the 39 observational studies, the majority, 21 (54.0\%), were cohort, while the rest were case-control (4, $10.2 \%)$, case-only $(8,20.5 \%)$, or unspecified $(6,15.4 \%)$. The study type was diverse as $29(74.0 \%)$ were prospective, 7 (18.0\%) were cross-sectional, $2(5.0 \%)$ were retrospective, and $1(2.5 \%)$ was not available. A majority of the clinical trials lasted for one to five years (Table 2).

\begin{tabular}{|c|c|c|}
\hline Duration & $\mathbf{N}$ & $\%$ \\
\hline$<1$ year & 8 & $10.0 \%$ \\
\hline $1-5$ years & 35 & $43.8 \%$ \\
\hline$>5$ years & 9 & $11.3 \%$ \\
\hline Ongoing & 28 & $35.0 \%$ \\
\hline
\end{tabular}

TABLE 2: Number of Clinical Trials Stratified by Study Length

Of all clinical trials, 28 (35\%) are studying NPH. Of these studies, eight are studying the effectiveness of VPS to improve current techniques, four focus on improving current imaging techniques for diagnosis, three are studying CSF biomarkers for diagnosis, two compare the effects of ETV to VPS for treatment, two are studying cognitive and development outcomes, and two are studying CSF dynamics to optimize treatment. One robust study is focused on building a registry, studying vascular risk factors, improving patient education, elucidating potential drug targets, improving gait treatments, improving treatments of urinary 
Of all clinical trials, 25 (31.3\%) are studying pediatric hydrocephalus. Of these studies, six are studying improving shunt function, six focus on improving current imaging modalities and advancing novel imaging techniques for diagnosis, five compare the effects of ETV to VPS for treatment, two provide data for registries to support hypothesis generation and study design development for clinical trials, two are studying cognitive and development outcomes, two are testing potential alternative anesthetics for obtaining MRI in this challenging population, one is studying CSF biomarkers to assess the severity of disease and response to treatment, and one is studying head circumference of hydrocephalic Ehlers-Danlos patients who develop dysautonomia later in life.

Of all clinical trials, four (5.0\%) are studying post-hemorrhagic hydrocephalus. These trials are examining whether early use of lumbar puncture leads to less shunt surgery, assessing the optimal conditions for EVD cessation, determining the role of proteomics in cerebral vasospasm following $\mathrm{SAH}$, and evaluating hydrocephalus as a predictor of functional disability and quality of life.

The remaining 23 (28.8\%) trials study all forms of hydrocephalus. Ten trials are examining the effectiveness of VPS and improving current techniques for treatment, five are focused on improving current imaging techniques for diagnosis, two are studying alternative methods to measure intracranial pressure, two are investigating CSF flow dynamics, and one study each is focused on patient education, prevention, and improving cognitive function.

To date, only four of the 44 completed trials have posted a statistical analysis on ClincalTrials.gov. Efforts were made to obtain the results of the other 40 trials and a search of the Medline database demonstrated that 20 of the studies had published results in peer-reviewed literature.

\section{Discussion}

Advancements in the diagnosis and treatment of hydrocephalus have rapidly improved over the last century [12]. From the first attempt to create a permanent ventriculo-subarachnoid-subgaleal CSF diversion by Mikulicz in 1893, to the first functional valve implantation devised by Nulsen and Spitz in 1949, the basis of treatment for hydrocephalus has largely remained the same $[13,14]$. In spite of several innovations and technical modifications, shunts, which have evolved and matured to become the standard of care for all types of hydrocephalus, are not without complications [15]. Further, since shunts remain a source of lifetime concern for the patient, parents, and family, the desire for shunt freedom has led to a resurgence of ETV techniques and other endeavors that aim to change the current standard [16]. Of the different types of hydrocephalus, NPH and pediatric hydrocephalus have generated the most research interest and comprise a majority of the current clinical trial registry.

There has been a sharp increase in the number of trials being conducted since 2013, which holds promise for future trends in hydrocephalus research and clinical management. This study found that the clinical trials were almost evenly split into interventional and observational studies. This demonstrates that while great advancements have been made for the treatment of hydrocephalus, there remains much room for improvements in current interventions due to the low number of interventional clinical trials. While more than half of the trials are reported as complete, only four have results available on ClinicalTrials.gov and only 20 of these have published their results in peer-reviewed literature. Therefore, there should be an encouragement for the neurosurgical community to publish results of all clinical trials, even if the findings are null or negative.

NPH is the most common form of hydrocephalus in adults, and it is estimated that over 700,000 people in the United States have NPH. It is characterized by dilated cerebral ventricles and it presents with a clinical trial involving impaired gait, cognition, and urinary control [17]. It is estimated that over 700,000 people in the United States have NPH [18]. Pediatric hydrocephalus has a prevalence of approximately 6 in 10,000 live births, with a neonatal mortality rate of $13 \%$ before hospital discharge [19]. According to nationally representative data from 2008, pediatric hydrocephalus accounts for 38,200 to 39,900 hospital admissions, 391,000 to 433,000 hospital days, and $\$ 1.4$ to $\$ 2.0$ billion in total hospital charges annually in the United States [20]. Because NPH and pediatric hydrocephalus are both prevalent diseases with a high cost of care, the completion and publication of the ongoing research will help clarify causes, hasten diagnosis, improve treatment, and increase the quality of life.

NPH is difficult to diagnose because of its insidious onset and nonspecific symptomatology. However, it is one of only a few reversible causes of dementia, making early diagnosis critical. The published results of clinical trials studying NPH demonstrate that much remains to be learned from this complex pathology and that NPH is a multi-etiological clinical entity, possibly overlapping pathophysiologically with cerebrovascular disease and Alzheimer's disease [21]. A high level of clinical suspicion is necessary to piece together the clinical picture and ultimately make the diagnosis. MRI is a useful modality because it allows for MR phase imaging of CSF flow which provides pathophysiological information of potential clinical importance [22]. Additionally, new neuropsychological tests have been developed to assess cognitive 


\section{Cureus}

impairment, which can assist in early diagnosis and improve outcomes [23].

Current evidence-based guidelines and best practices for hydrocephalus treatment suggest that shunts are superior to ETV in infants [24]. Regarding imaging, the degree of fetal ventriculomegaly based on the ultrasound and MRI measurements had a predictive value for successful live birth while ultrasound-guided shunt insertion was unable to consistently place catheters into the frontal horn of the ventricles. However, laparoscopically guided distal VPS placement provides definite patient benefit by allowing shunt placement under direct vision, all while allowing for reduced trauma to the abdominal wall and avoiding intraabdominal adhesions [25-27].

A majority of the clinical trials of hydrocephalus included in the database have begun over the last five years. Since the average time to completion of the completed trials was 50 months, we can expect a host of new results to become available over the next few years. Practitioners should anticipate the publication of these results and look for practice-changing recommendations.

\section{Limitations}

First, while ClinicalTrials.gov accounts for more than $80 \%$ of all studies in the World Health Organization's International Clinical Trials Registry platform, it does not include all clinical trials [28]. Second, this study only analyzes the characteristics of the registered trials but does not assess the quality of the research being conducted. As more data become available, the quality of the research will have to be further scrutinized.

\section{Conclusions}

The current study provides an overview of registered trials on ClinicalTrials.gov studying hydrocephalus. Approximately half of the trials are interventional and half are observational. A majority of the trials are studying NPH and pediatric hydrocephalus. While 44 trials are complete, only 20 have published results in peer review highlighting the need to translate these results into peer-reviewed publications for the edification of the neurosurgical community. Doing so will only serve to further the growing trend in hydrocephalus research, offering hope to patients and their families.

\section{Appendices}

\begin{tabular}{|c|c|c|c|c|c|}
\hline $\begin{array}{l}\text { ClinicalTrials.gov } \\
\text { Identifier }\end{array}$ & Official title & $\begin{array}{l}\text { Type of } \\
\text { Hydrocephalus }\end{array}$ & Country & $\begin{array}{l}\text { Intervention (if } \\
\text { applicable) }\end{array}$ & Primary outcome \\
\hline NCT01936272 & $\begin{array}{l}\text { Neurocognitive Outcomes and Changes } \\
\text { in Brain and Cerebral Spinal Fluid (CSF) } \\
\text { Volume After Treatment of Post- } \\
\text { Infectious Hydrocephalus (PIH) in } \\
\text { Ugandan Infants by Shunting Versus } \\
\text { ETV/CPC }\end{array}$ & $\begin{array}{l}\text { Neonatal } \\
\text { postinfectious } \\
\text { hydrocephalus }\end{array}$ & Uganda & placement & Change of age-normed BSID-III scores \\
\hline NCT01909960 & $\begin{array}{l}\text { Benefit of Flow Magnetic Resonance } \\
\text { Imaging in the Management of Normal } \\
\text { Pressure Hydrocephalus }\end{array}$ & $\mathrm{NPH}$ & France & Flow imaging & CSF stroke volume evolution other six months \\
\hline NCT02230124 & $\begin{array}{l}\text { Magnetic Resonance Elastography in } \\
\text { Hydrocephalus }\end{array}$ & $\begin{array}{l}\text { Neonatal } \\
\text { postinfectious } \\
\text { hydrocephalus }\end{array}$ & USA & $\begin{array}{l}\text { MRE (magnetic } \\
\text { resonance } \\
\text { elastography) }\end{array}$ & Mean shear modulus \\
\hline NCT02425761 & $\begin{array}{l}\text { A Randomized Controlled Trial of } \\
\text { Anterior Versus Posterior Entry Site for } \\
\text { Cerebrospinal Fluid Shunt Insertion }\end{array}$ & $\begin{array}{l}\text { Pediatric } \\
\text { hydrocephalus }\end{array}$ & USA, Canada & $\begin{array}{l}\text { Ventriculoperitoneal } \\
\text { shunt insertion } \\
\text { surgery }\end{array}$ & $\begin{array}{l}\text { Shunt failure determined by clinical and } \\
\text { radiographic findings }\end{array}$ \\
\hline NCT01797627 & $\begin{array}{l}\text { Ventricular Size Involvement in } \\
\text { Neuropsychological Outcomes in } \\
\text { Pediatric Hydrocephalus (VINOH) }\end{array}$ & $\begin{array}{l}\text { Congenital } \\
\text { hydrocephalus }\end{array}$ & USA, Canada & & $\begin{array}{l}\text { Association between ventricle size and } \\
\text { neuropsychological outcome }\end{array}$ \\
\hline \multirow[t]{2}{*}{ NCT01041950 } & $\begin{array}{l}\text { Lumbar Drainage for } \\
\text { Communicating Hydrocephalus After } \\
\text { Intraventricular Hemorrhage: A } \\
\text { Randomised, Controlled Trial (LUCAS- } \\
\text { IVH: LUmbar CAtheter for Severe } \\
\text { IntraVentricular Hemorrhage) }\end{array}$ & $\begin{array}{l}\text { Post- } \\
\text { hemorrhagic } \\
\text { hydrocephalus }\end{array}$ & Germany & Lumbar drainage & The requirement of permanent VPS \\
\hline & Efficacy of Shunt Surgery in Normal & & & $\begin{array}{l}\text { MIETHKE } \\
\text { proGAV } \otimes / M I E T H K E\end{array}$ & $\begin{array}{l}\text { 1. Tinetti score on open shunt vs. closed shunt } 2 . \\
\text { TUG score on open shunt vs. closed shunt } 3 . \\
\text { Medical College of Virginia (MCV) Gait Grade on }\end{array}$ \\
\hline
\end{tabular}




\section{Cureus}

\begin{tabular}{|c|c|c|c|c|c|}
\hline NCT01798641 & $\begin{array}{l}\text { Pressure Hydrocephalus: A } \\
\text { Randomized Cross-Over Study }\end{array}$ & NPH & USA & $\begin{array}{l}\text { proSA } \AA \text { (Braun, } \\
\text { Tuttlingen, } \\
\text { Germany) }\end{array}$ & $\begin{array}{l}\text { open shunt vs. closed shunt } 4 \text {. Kiefer score on } \\
\text { open shunt vs. closed shunt } 5 \text {. Kubo score on } \\
\text { open shunt vs. closed shunt }\end{array}$ \\
\hline NCT02651337 & $\begin{array}{l}\text { Quantitative Characterization of Safe } \\
\text { Irrigation for Ventricular Shunt Catheters }\end{array}$ & All & USA & Alivio in line flusher & $\begin{array}{l}\text { Characterization of safe shunt catheter "flushing" } \\
\text { using a quantitative assessment of saline injection } \\
\text { volume (mls) required to flush the CSF shunt using } \\
\text { the Alivio in-line Flusher }\end{array}$ \\
\hline NCT00286104 & $\begin{array}{l}\text { The Impact of Ventricular Catheter } \\
\text { Impregnated With Antimicrobial Agents } \\
\text { on Infection in Patients With Ventricular } \\
\text { Catheter: A Prospective Randomized } \\
\text { Study }\end{array}$ & All & China & $\begin{array}{l}\text { Antibiotics- } \\
\text { impregnated } \\
\text { ventricular catheter } \\
\text { (Bactiseal } \circledast \text {, } \\
\text { Codman, Johnson } \\
\text { \& Johnson, } \\
\text { Raynham, USA) }\end{array}$ & 1. CSF infection rate 2. Extracranial infection rate \\
\hline NCT02575105 & $\begin{array}{l}\text { Bispectral Index Monitoring of Propofol } \\
\text { Anesthesia in Patients } \\
\text { With Hydrocephalus: A Prospective } \\
\text { Observational Study }\end{array}$ & $\begin{array}{l}\text { Congenital } \\
\text { hydrocephalus }\end{array}$ & Austria & $\begin{array}{l}\text { Bispectral index } \\
\text { value }\end{array}$ & The difference in bispectral index value \\
\hline NCT01815775 & $\begin{array}{l}\text { Predictive Value of Flow MRI in Normal } \\
\text { Pressure Hydrocephalus Surgery }\end{array}$ & $\mathrm{NPH}$ & France & $\begin{array}{l}\text { Clinical and imaging } \\
\text { examinations }\end{array}$ & CSF stroke volume \\
\hline NCT00196196 & $\begin{array}{l}\text { A Precision and Accuracy Study of the } \\
\text { Codman Valve Position Verification } \\
\text { (VPV) System }\end{array}$ & All & USA & $\begin{array}{l}\text { Codman VPV } \\
\text { system }\end{array}$ & $\begin{array}{l}\text { Percentage of participants who achieved } \\
\text { "adjustment complete" and a consensus X-ray } \\
\text { reading }\end{array}$ \\
\hline NCT01265251 & $\begin{array}{l}\text { Evaluation of a Computerised } \\
\text { Neuropsychological Test Battery for } \\
\text { Idiopathic Normal } \\
\text { Pressure Hydrocephalus (INPH) }\end{array}$ & $\mathrm{NPH}$ & Sweden & $\begin{array}{l}\text { Computerized } \\
\text { neuropsychological } \\
\text { test }\end{array}$ & 1. Validity; 2. reliability; 3. feasibility \\
\hline NCT00600795 & $\begin{array}{l}\text { Prognostic Value of Transforming } \\
\text { Growth Factor-Beta } 1 \text { in Normal } \\
\text { Pressure Hydrocephalus }\end{array}$ & $\mathrm{NPH}$ & USA & CSF collection & $\begin{array}{l}\text { 1. TGF beta-1 levels } 2 \text {. Mini-mental status exam } 3 \text {. } \\
\text { Modified Barthel index } 4 \text {. Tinetti mobility } \\
\text { assessment }\end{array}$ \\
\hline NCT01801267 & $\begin{array}{l}\text { A Randomized Controlled Trial of } \\
\text { Endoscopic Third Ventriculostomy } \\
\text { Versus Ventricular Shunt for Children } \\
\text { With Communicating Hydrocephalus }\end{array}$ & $\begin{array}{l}\text { Communicating } \\
\text { hydrocephalus }\end{array}$ & USA & $\begin{array}{l}\text { Endoscopic third } \\
\text { ventriculostomy }\end{array}$ & $\begin{array}{l}\text { Time until the need for further CSF-related } \\
\text { surgeries }\end{array}$ \\
\hline NCT00652470 & $\begin{array}{l}\text { International } \\
\text { Infant Hydrocephalus Study: A } \\
\text { Multicentre, Prospective Study }\end{array}$ & TVH & $\begin{array}{l}\text { USA, Argentina, } \\
\text { Brazil, Canada, } \\
\text { Germany, } \\
\text { Hungary, India, } \\
\text { Israel, Italy, } \\
\text { Netherlands, } \\
\text { Poland, Russia, } \\
\text { Serbia, Spain, } \\
\text { Turkey, UK }\end{array}$ & $\begin{array}{l}\text { Endoscopic third } \\
\text { ventriculostomy }\end{array}$ & $\begin{array}{l}\text { Health status outcome as measured by the Health } \\
\text { Utilities Index }\end{array}$ \\
\hline NCT01053312 & $\begin{array}{l}\text { A Principal, Open-Label, Single Center } \\
\text { Study to Validate the Detection of } \\
\text { Cerebral Cortical Amyloid With } \\
\text { Flutemetamol (18F) Injection in Subjects } \\
\text { Previously Biopsied }\end{array}$ & NPH & USA & Flutemetamol & $\begin{array}{l}\text { 1. Quantitative estimates of brain uptake [18F] } \\
\text { Flutemetamol and the quantitative IHC estimates } \\
\text { of amyloid levels in biopsy samples previously } \\
\text { obtained 2. Comparison between brain uptake of } \\
\text { [18F] Flutemetamol amyloid level from IHC assay } \\
\text { and a stained biopsy tissue specimen }\end{array}$ \\
\hline NCT03595033 & $\begin{array}{l}\text { iPad Application Based Therapy } \\
\text { Intervention in School Age Children With } \\
\text { Surgically Treated Hydrocephalus }\end{array}$ & $\begin{array}{l}\text { Pediatric } \\
\text { hydrocephalus }\end{array}$ & USA & $\begin{array}{l}\text { iPad app-based } \\
\text { intervention }\end{array}$ & $\begin{array}{l}\text { 1. General intellectual functioning, including visual- } \\
\text { spatial reasoning 2. Basic visual perception, visual- } \\
\text { motor integration, and graphomotor skills } 3 \text {. Visual- } \\
\text { spatial processing } 4 \text {. Visual-spatial processing and } \\
\text { mental rotation } 5 \text {. Selective visual attention } 6 \text {. } \\
\text { Visual-spatial decision making and visual-motor } \\
\text { speed 7. Fine motor dexterity } 8 \text {. Visual-motor } \\
\text { control 9. Neuroanatomical alterations in brain } \\
\text { tissue structure }\end{array}$ \\
\hline
\end{tabular}




\section{Cureus}

\begin{tabular}{|c|c|c|c|c|c|}
\hline NCT01115270 & $\begin{array}{l}\text { A Study Comparing Shunt Placement } \\
\text { Versus Endoscopic Third } \\
\text { Ventriculostomy in the Treatment } \\
\text { of Hydrocephalus }\end{array}$ & $\mathrm{NPH}$ & USA & $\begin{array}{l}\text { Non-invasive } \\
\text { measures }\end{array}$ & Intracranial compliance \\
\hline NCT00743457 & $\begin{array}{l}\text { Pediatric Ocular Ultrasound for VPS } \\
\text { Failure }\end{array}$ & $\begin{array}{l}\text { Pediatric } \\
\text { hydrocephalus }\end{array}$ & USA & Ocular ultrasound & $\begin{array}{l}\text { 1. Optic nerve sheath diameter } 2 \text {. Clinical VPS } \\
\text { failure }\end{array}$ \\
\hline NCT02016352 & $\begin{array}{l}\text { Cerebrospinal Fluid Proteome } \\
\text { in Hydrocephalus }\end{array}$ & $\mathrm{NPH}$ & France & $\begin{array}{l}\text { patient CSF } \\
\text { extraction with } \\
\text { hydrocephalus }\end{array}$ & CSF proteome measure \\
\hline NCT01323764 & $\begin{array}{l}\text { A Double-Blinded Comparison of the } \\
\text { Accuracy of ShuntCheck, a Non- } \\
\text { Invasive Device, to Radionuclide Shunt } \\
\text { Patency Test in Evaluating Shunt } \\
\text { Function in Patients With } \\
\text { Adult Hydrocephalus With Possible } \\
\text { Shunt Obstruction }\end{array}$ & $\mathrm{NPH}$ & USA & Shunt check test & Sensitivity and specificity of ShuntCheck vs SPS \\
\hline NCT03113799 & $\begin{array}{l}\text { A Study to Evaluate the Performance } \\
\text { and Safety of Aqueduct's Smart } \\
\text { External Device (SED) Compared to } \\
\text { Standard EVD Drains }\end{array}$ & All & USA & $\begin{array}{l}\text { Smart external } \\
\text { drain }\end{array}$ & Staff interactions \\
\hline NCT01811589 & $\begin{array}{l}\text { Randomized Controlled Multi-Center } \\
\text { Trial Comparing the Ventricular Catheter } \\
\text { Location Between Instrument Guided } \\
\text { and Freehand Placement }\end{array}$ & All & Germany & Thomale-guide & $\begin{array}{l}\text { Rate of the primary successful ventricular catheter } \\
\text { placement with a grade I or grade lb and location } \\
\text { in the ipsilateral ventricle }\end{array}$ \\
\hline NCT01976559 & $\begin{array}{l}\text { Comparison of Continuous Noninvasive } \\
\text { and Invasive Intracranial Pressure } \\
\text { Measurement - Celda Infusion } \\
\text { Subprotocol }\end{array}$ & All & Sweden & $\begin{array}{l}\text { Tympanic } \\
\text { membrane } \\
\text { displacement }\end{array}$ & Noninvasive ICP \\
\hline NCT02325583 & $\begin{array}{l}\text { Baskent University Institutional Review } \\
\text { Board }\end{array}$ & All & Turkey & & $\begin{array}{l}\text { Number of newborns provided qualitative images } \\
\text { for MRI following oral glucose administration }\end{array}$ \\
\hline NCT00182390 & $\begin{array}{l}\text { A Randomized Controlled Trial of Two } \\
\text { Hemoglobin Thresholds for Transfusion } \\
\text { in Newborns }<1000 \mathrm{~g} \text { Birth Weight }\end{array}$ & All & USA & & $\begin{array}{l}\text { 1. Combined mortality or survival to tertiary } \\
\text { hospital discharge without severe morbidity } 2 \text {. } \\
\text { Combined mortality or survival with } \\
\text { neurodevelopmental disability (non-ambulatory } \\
\text { cerebral palsy, blindness, deafness, and cognitive } \\
\text { delay) }\end{array}$ \\
\hline NCT01799018 & $\begin{array}{l}\text { Role of Proteomics and Metallomics in } \\
\text { Cerebral Vasospasm Following } \\
\text { Subarachnoid Hemorrhage }\end{array}$ & All & USA & & $\begin{array}{l}\text { 1. Protein identification and concentration 2. Metal } \\
\text { ion identification and concentration }\end{array}$ \\
\hline NCT00280904 & $\begin{array}{l}\text { A Registry for Comparing Catheter- } \\
\text { Related Infection Rates Among Various } \\
\text { Shunt Systems in the Treatment } \\
\text { of Hydrocephalus }\end{array}$ & All & $\begin{array}{l}\text { USA, Canada, } \\
\text { China, } \\
\text { Singapore, India }\end{array}$ & & Number of subjects with shunt infections \\
\hline NCT01885468 & $\begin{array}{l}\text { X-Ray Verified Accuracy of the Aesculap } \\
\text { - Miethke proGAV Adjustable Shunt } \\
\text { Pressure Setting Verification Instrument }\end{array}$ & All & USA & & $\begin{array}{l}\text { Level of agreement between the proGAV } \circledast \\
\text { verification instrument measurement and X-ray } \\
\text { control measurements }\end{array}$ \\
\hline NCT02381977 & $\begin{array}{l}\text { Prevalence of Acute Critical } \\
\text { Neurological Disease in Children: A } \\
\text { Global Epidemiological Assessment }\end{array}$ & All & USA & & Prevalence of acute brain insult \\
\hline NCT00870675 & $\begin{array}{l}\text { MRI of Ventriculomegaly: Morphology } \\
\text { and Outcome }\end{array}$ & $\begin{array}{l}\text { Fetal } \\
\text { ventriculomegaly }\end{array}$ & USA & & $\begin{array}{l}\text { 1. Postnatal imaging abnormalities } 2 \text {. Postnatal } \\
\text { developmental delay }\end{array}$ \\
\hline NCT00221091 & $\begin{array}{l}\text { Clinical Study of Idiopathic Normal } \\
\text { Pressure Hydrocephalus for } \\
\text { Neurological Improvement }\end{array}$ & NPH & Japan & & Modified Rankin scale score \\
\hline NCT00233701 & $\begin{array}{l}\text { Normal Pressure Hydrocephalus (NPH) } \\
\text { Registry }\end{array}$ & $\mathrm{NPH}$ & SA & & $\begin{array}{l}\text { Database to describe the population of patients } \\
\text { with NPH presenting for treatment }\end{array}$ \\
\hline
\end{tabular}




\section{Cureus}

\begin{tabular}{|c|c|c|c|c|}
\hline NCT01374048 & $\begin{array}{l}\text { Are Intracranial Pressure Waves } \\
\text { Measurable Through Lumbar Puncture? }\end{array}$ & NPH & $\begin{array}{l}\text { No contacts or } \\
\text { locations } \\
\text { provided }\end{array}$ & Not available \\
\hline NCT00001327 & $\begin{array}{l}\text { Establishing the Physiology of } \\
\text { Syringomyelia }\end{array}$ & NPH & USA & Not available \\
\hline NCT01319136 & $\begin{array}{l}\text { Novel Infusion Method for Describing } \\
\text { CSF Dynamics }\end{array}$ & NPH & Sweden & Not available \\
\hline NCT01570257 & $\begin{array}{l}\text { A Randomized Trial of High and Low } \\
\text { Pressure Level Settings on a } \\
\text { Programmable Ventriculoperitoneal } \\
\text { Shunt Valve for Idiopathic Normal } \\
\text { Pressure Hydrocephalus: Results of the } \\
\text { Dutch Evaluation Program Strata Shunt } \\
\text { (DEPSS) Trial }\end{array}$ & NPH & Netherlands & $\begin{array}{l}\text { The number of subdural effusions, detected on CT } \\
\text { scan, in patients showing clinical improvement } \\
\text { after implantation of a ventriculoperitoneal shunt, } \\
\text { at the end of the study }\end{array}$ \\
\hline NCT01850914 & $\begin{array}{l}\text { Vascular Risk Factors, Subclinical and } \\
\text { Manifest Vascular Disease in Patients } \\
\text { With Idiopathic Normal } \\
\text { Pressure Hydrocephalus }\end{array}$ & $\begin{array}{l}\text { Pediatric } \\
\text { hydrocephalus }\end{array}$ & Sweden & $\begin{array}{l}\text { Differences in blood pressure between INPH- } \\
\text { patients and sex- and age-matched community- } \\
\text { based population }\end{array}$ \\
\hline NCT01739179 & $\begin{array}{l}\text { Laparoscopically Assisted } \\
\text { Ventriculoperitoneal Shunt Placement: A } \\
\text { Prospective, Randomized Two-Arm } \\
\text { Study }\end{array}$ & $\begin{array}{l}\text { Pediatric } \\
\text { hydrocephalus }\end{array}$ & Switzerland & The number of patients with overall shunt failure \\
\hline NCT00652197 & $\begin{array}{l}\text { A Flow Monitor for Pediatric } \\
\text { Hydrocephalic Shunts - Flow Sensor } \\
\text { Study }\end{array}$ & $\begin{array}{l}\text { Pediatric } \\
\text { hydrocephalus }\end{array}$ & USA & $\begin{array}{l}\text { Volumetric flow of patient CSF through an extra- } \\
\text { ventricular drainage system }\end{array}$ \\
\hline NCT01007786 & $\begin{array}{l}\text { The Ventricular Catheter Placement } \\
\text { Study: Assessment of Efficacy and } \\
\text { Safety of an Ultrasound Guided Shunt } \\
\text { Insertion Technique }\end{array}$ & $\begin{array}{l}\text { Pediatric } \\
\text { hydrocephalus }\end{array}$ & USA, Canada & $\begin{array}{l}\text { The primary endpoint for the study is VCL as } \\
\text { assessed on the first post-operative scan (US, CT, } \\
\text { or MRI brain) }\end{array}$ \\
\hline NCT01556178 & $\begin{array}{l}\text { Collection of Blood and Cerebrospinal } \\
\text { Fluid for Pediatric Brain Tumor Research }\end{array}$ & $\begin{array}{l}\text { Pediatric } \\
\text { hydrocephalus }\end{array}$ & USA & Levels of miRNAs in the blood and CSF. \\
\hline NCT01367977 & $\begin{array}{l}\text { Head Circumference Growth in Children } \\
\text { With Ehlers-Danlos Syndrome Who } \\
\text { Develop Dysautonomia ("POTS" - } \\
\text { Postural Orthostatic Tachycardia } \\
\text { Syndrome) Later in Life - A } \\
\text { Retrospective Analysis }\end{array}$ & $\begin{array}{l}\text { Pediatric } \\
\text { hydrocephalus }\end{array}$ & USA & $\begin{array}{l}\text { Measurement of head circumference in Ehlers- } \\
\text { Danlos patients (retrospectively), between the ages } \\
\text { of birth and } 15 \text { months of age }\end{array}$ \\
\hline NCT00692744 & $\begin{array}{l}\text { Study of Quality of Life After Aneurysmal } \\
\text { Subarachnoid Hemorrhage in Patients } \\
\text { Aged } 70 \text { Years or Older }\end{array}$ & $\begin{array}{l}\text { Post- } \\
\text { hemorrhagic } \\
\text { hydrocephalus }\end{array}$ & France & Modified Rankin scale score \\
\hline NCT01480349 & $\begin{array}{l}\text { Shunt Outcomes of Post- } \\
\text { Hemorrhagic Hydrocephalus: A Network } \\
\text { Pilot Study }\end{array}$ & $\begin{array}{l}\text { Post- } \\
\text { hemorrhagic } \\
\text { hydrocephalus }\end{array}$ & USA, Canada & $\begin{array}{l}\text { The proportion of temporization, conversion } \\
\text { proportion, and surgery checklist scores }\end{array}$ \\
\hline NCT00747682 & $\begin{array}{l}\text { Alterations in Cerebral Perfusion, } \\
\text { Oxygenation, Electrical Activity, and } \\
\text { Markers of Cerebral Damage } \\
\text { Associated With Cerebro-Spinal Fluid } \\
\text { Reservior Aspiration in Neonates With } \\
\text { Post Hemorrhagic Hydrocephalus }\end{array}$ & $\begin{array}{l}\text { Post- } \\
\text { hemorrhagic } \\
\text { hydrocephalus }\end{array}$ & USA & $\begin{array}{l}\text { Determine if decreasing ventricular volume } \\
\text { improves middle cerebral artery flow, cerebral } \\
\text { oxygenation, and cortical neuronal electrical } \\
\text { activity }\end{array}$ \\
\hline NCT01108965 & $\begin{array}{l}\text { A Flow Monitor for Pediatric } \\
\text { Hydrocephalic Shunts }\end{array}$ & $\begin{array}{l}\text { Post- } \\
\text { hemorrhagic } \\
\text { hydrocephalus }\end{array}$ & USA & $\begin{array}{l}\text { The volumetric flow of patient cerebrospinal fluid } \\
\text { through an extra-ventricular drainage system }\end{array}$ \\
\hline NCT00875758 & $\begin{array}{l}\text { Phase II Study of Late Versus Early } \\
\text { Treatment of Post-hemorrhagic } \\
\text { Ventricular Dilation in Preterm Infants }\end{array}$ & $\begin{array}{l}\text { Post- } \\
\text { hemorrhagic } \\
\text { hydrocephalus }\end{array}$ & USA & Ventriculoperitoneal shunt-dependence \\
\hline
\end{tabular}




\section{Cureus}

\begin{tabular}{|c|c|c|c|c|c|}
\hline NCT03076723 & $\begin{array}{l}\text { Using Cerebrospinal Fluid Dynamics to } \\
\text { Identify Shunt Responders in Idiopathic } \\
\text { Normal Pressure Hydrocephalus and to } \\
\text { Optimize Postoperative Clinical } \\
\text { Improvement While Minimizing } \\
\text { Overdrainage Related Complications - A } \\
\text { Double Blind Randomized Study }\end{array}$ & $\mathrm{NPH}$ & $\begin{array}{l}\text { Finland, } \\
\text { Sweden }\end{array}$ & $\begin{array}{l}\text { Simulated change } \\
\text { in shunt opening } \\
\text { pressure }\end{array}$ & $\begin{array}{l}\text { 1. Change in total score on the European INPH } \\
\text { scale } 2 \text {. Gait velocity } 3 \text {. European INPH scale } 4 . \\
\text { Gait velocity }\end{array}$ \\
\hline NCT02404740 & $\begin{array}{l}\text { Continuous Noninvasive Estimation of } \\
\text { Intracranial Pressure to Assess } \\
\text { Ventriculoperitoneal Shunt Malfunction } \\
\text { in Patients With Hydrocephalus }\end{array}$ & All & USA & & $\begin{array}{l}\text { The presence or absence of ventriculoperitoneal } \\
\text { shunt malfunction in patients with hydrocephalus }\end{array}$ \\
\hline NCT03650101 & $\begin{array}{l}\text { Improving } \\
\text { Infant Hydrocephalus Outcomes in } \\
\text { Uganda: Predicting Developmental } \\
\text { Outcomes and Identifying Patients at } \\
\text { Risk for Early Treatment Failure After } \\
\text { ETV/CPC }\end{array}$ & NPH & USA & ETV/CPC & $\begin{array}{l}\text { 1. BSID-III, cognitive-scaled score, the incidence } \\
\text { of ETV/CPC treatment failure 2. Incidence of } \\
\text { ETV/CPC treatment failure }\end{array}$ \\
\hline NCT03269201 & $\begin{array}{l}\text { Mapping Functional Networks of Brain } \\
\text { Activity (Brain Network Activation, BNA) } \\
\text { Based on Analysis of Evoked Response } \\
\text { Potential (ERP) EEG Signals in Patients } \\
\text { With Movement Disorders }\end{array}$ & All & Israel & & MDS-UPDRS part III score \\
\hline NCT03828032 & $\begin{array}{l}\text { Alternations of Multi-Parameters } \\
\text { Including Hemodynamic Concentration } \\
\text { and Water Levels During Dehydration } \\
\text { Therapy on Brain Edema Patients }\end{array}$ & All & China & & $\begin{array}{l}\text { 1. Changes in oxyhemoglobin concentration } 2 \text {. } \\
\text { Water concentration }\end{array}$ \\
\hline NCT03826056 & $\begin{array}{l}\text { Neurology Inpatient Clinical Education } \\
\text { Trial }\end{array}$ & $\mathrm{NPH}$ & USA & & Patient satisfaction scores \\
\hline NCT03777774 & $\begin{array}{l}\text { Vacuum Drains vs Passive Drains vs no } \\
\text { Drains in Decompressive Craniectomies } \\
\text { - A Randomized Controlled Trial on } \\
\text { Subgaleal Drain Complication Rates }\end{array}$ & $\begin{array}{l}\text { Pediatric } \\
\text { hydrocephalus }\end{array}$ & Malaysia & & Subgaleal hematomas \\
\hline NCT03779594 & $\begin{array}{l}\text { Acetazolamide for Treating NPH in } \\
\text { Shunt-Candidates Patients: An Open } \\
\text { Label Feasibility Trial }\end{array}$ & $\mathrm{NPH}$ & Israel & Acetazolamide & $\begin{array}{l}\text { 1. Change from baseline gait } 2 \text {. Change from } \\
\text { baseline balance }\end{array}$ \\
\hline NCT03471702 & $\begin{array}{l}\text { A Secondary Study Evaluating } \\
\text { Performance and Safety of Aqueduct's } \\
\text { Smart External Drain (SED2) }\end{array}$ & $\begin{array}{l}\text { Post- } \\
\text { hemorrhagic } \\
\text { hydrocephalus }\end{array}$ & USA & Aqueduct's SED & $\begin{array}{l}\text { The number of subjects who require switching to a } \\
\text { standard of care external drain }\end{array}$ \\
\hline NCT02900222 & $\begin{array}{l}\text { Study of Endoscopic Choroid Plexus } \\
\text { Cauterization for Adult Patients } \\
\text { With Hydrocephalus and Risk Factors } \\
\text { for Perioperative Complications } \\
\text { Following Shunt Surgery. }\end{array}$ & NPH & USA & $\begin{array}{l}\text { Endoscopic choroid } \\
\text { plexus coagulation }\end{array}$ & The occurrence of post-operative complications \\
\hline NCT03245138 & $\begin{array}{l}\text { Endoscopic Third Ventriculostomy } \\
\text { Versus Ventriculo-Peritoneal Shunting in } \\
\text { Idiopathic Normal } \\
\text { Pressure Hydrocephalus }\end{array}$ & NPH & Germany & ETV & Kiefer index \\
\hline NCT02495610 & $\begin{array}{l}\text { A Prospective Single-Centre Trial } \\
\text { Investigating Novel Parameters for the } \\
\text { Prediction of Ventriculoperitoneal } \\
\text { Shunting Efficacy in Patients With } \\
\text { Idiopathic Normal } \\
\text { Pressure Hydrocephalus }\end{array}$ & NPH & Switzerland & $\begin{array}{l}\text { Gait analysis and } \\
\text { MRI }\end{array}$ & MRI \\
\hline NCT02659111 & $\begin{array}{l}\text { Effects of Physical Training in Shunt- } \\
\text { Operated Patients With Idiopathic } \\
\text { Normal Pressure Hydrocephalus }\end{array}$ & NPH & Sweden & HIFE & 1. Change in INPH-scale 2. Change in GAS \\
\hline & $\begin{array}{l}\text { RCT of Feeding Intervention With } \\
\text { Pacifier Activated Device and Mother's }\end{array}$ & Congenital & & acifier-activated & \\
\hline
\end{tabular}




\section{Cureus}

\begin{tabular}{|c|c|c|c|c|c|}
\hline NCT03230032 & $\begin{array}{l}\text { Voice in Infants at High-risk for Cerebral } \\
\text { Palsy }\end{array}$ & hydrocephalus & USA & $\begin{array}{l}\text { device (PAL) } \\
\text { system }\end{array}$ & Oral feeding efficiency \\
\hline NCT03877107 & $\begin{array}{l}\text { Effect of Depletive Lumbar Puncture and } \\
\text { Cerebrospinal Fluid Shunt Surgery on } \\
\text { Lower Urinary Tract Dysfunction in } \\
\text { Normal Pressure Hydrocephalus }\end{array}$ & NPH & France & $\begin{array}{l}\text { Urinary symptoms } \\
\text { profile } \\
\text { questionnaire }\end{array}$ & $\begin{array}{l}\text { 1. Effect of depletive lumbar puncture on } \\
\text { overactive bladder symptoms } 2 \text {. Effect of depletive } \\
\text { lumbar puncture on overactive bladder symptoms }\end{array}$ \\
\hline NCT03092804 & $\begin{array}{l}\text { The Brain Structure and Neural Network } \\
\text { Changing the Before and After } \\
\text { Ventriculo-Peritoneal Shunting in the } \\
\text { Normal Pressure Hydrocephalus } \\
\text { Patients }\end{array}$ & NPH & China & $\begin{array}{l}\text { Ventriculo- } \\
\text { peritoneal shunting }\end{array}$ & $\begin{array}{l}\text { 1. The brain constructure and neural network } \\
\text { changing one day after shunting } 2 \text {. The brain } \\
\text { constructure and neural network changing } 90 \text { days } \\
\text { after shunting } 3 \text {. The brain constructure and neural } \\
\text { network changing one year after shunting }\end{array}$ \\
\hline NCT03531723 & $\begin{array}{l}\text { Brain Ultrasound in the Weaning of } \\
\text { External Ventricular Leads }\end{array}$ & All & France & & $\begin{array}{l}\text { 1. Inter-individual reproducibility of ultrasound } \\
\text { measurement of the size of the third ventricle } 2 \text {. } \\
\text { Intra-individual reproducibility of ultrasound } \\
\text { measurement of the size of the third ventricle } 3 \text {. } \\
\text { Intra-individual reproducibility of ultrasound } \\
\text { measurement of the size of the third ventricle }\end{array}$ \\
\hline NCT03382860 & $\begin{array}{l}\text { Estimation of Intracranial Pressure } \\
\text { Using Non-Invasive Fundus Videos }\end{array}$ & All & Denmark & & $\begin{array}{l}\text { Absolute } \mathrm{A} / \mathrm{V} \text { ratio value to conventional } \\
\text { intracranial pressure monitors }\end{array}$ \\
\hline NCT02737163 & $\begin{array}{l}\text { Inadvertent Cerebral Spinal Fluid Valve } \\
\text { Reprogramming: Prevalence and the } \\
\text { Correlation With Signs, Symptoms, } \\
\text { Radiographic Changes and the } \\
\text { Exposure to Magnetic Fields. }\end{array}$ & All & USA & & $\begin{array}{l}\text { Frequency of inadvertent reprogramming of strata } \\
\text { CSF shunt valves }\end{array}$ \\
\hline NCT03698838 & $\begin{array}{l}\text { A Pilot, Prospective Study of Myelin } \\
\text { Imaging Changes in Patients With } \\
\text { Neurosurgical Diseases }\end{array}$ & All & USA & & Myelin alterations read on MRI sequence \\
\hline
\end{tabular}




\section{Cureus}

\begin{tabular}{|c|c|c|c|c|}
\hline & Sedation for Pediatric Magnetic & \multicolumn{2}{|l|}{ hydrocephalus } & sedation compared with propofol infusion \\
\hline NCT00670735 & $\begin{array}{l}\text { HCRN Core Data Project: Characterizing } \\
\text { Patient Populations in } \\
\text { the Hydrocephalus Clinical Research } \\
\text { Network (HCRN) }\end{array}$ & $\begin{array}{l}\text { Pediatric } \\
\text { hydrocephalus }\end{array}$ & USA, Canada & $\begin{array}{l}\text { To describe the number and characteristics of } \\
\text { neurosurgical hydrocephalus patient events to } \\
\text { HCRN Clinical Centers such as patient } \\
\text { demographics, etiology of hydrocephalus, } \\
\text { diagnostic information, as well as surgical and } \\
\text { medical management decisions }\end{array}$ \\
\hline NCT02601339 & $\begin{array}{l}\text { Beside Monitor of Cerebral Metabolism } \\
\text { in Premature Infants With } \\
\text { Intraventricular Hemorrhage and Post- } \\
\text { Hemorrhagic Hydrocephalus }\end{array}$ & $\begin{array}{l}\text { Post- } \\
\text { hemorrhagic } \\
\text { hydrocephalus }\end{array}$ & USA & Cerebral oxygen metabolism (CMRO2) \\
\hline
\end{tabular}

\section{TABLE 3: List of Clinical Trials Included in the Final Analysis}

CSF: cerebrospinal fluid, VPS: ventriculoperitoneal shunting, ETV: endoscopic third ventriculostomy, NPH: normal pressure hydrocephalus, TVH: triventricular hydrocephalus, ETV/CPC: endoscopic third ventriculostomy with choroid plexus cauterization, SED: smart external drain, HIFE: high intensive functional exercise, PAL: pacifier-activated-lullaby, BSID-III: Bayley scales of infant development, third edition, TUG: timed up and go, IHC: immunohistochemical, ICP: intracranial pressure, INPH: idiopathic normal pressure hydrocephalus, VCL: ventricular catheter location, HCRN: Hydrocephalus Clinical Research Network.

\section{Additional Information}

\section{Disclosures}

Human subjects: All authors have confirmed that this study did not involve human participants or tissue. Animal subjects: All authors have confirmed that this study did not involve animal subjects or tissue. Conflicts of interest: In compliance with the ICMJE uniform disclosure form, all authors declare the following: Payment/services info: All authors have declared that no financial support was received from any organization for the submitted work. Financial relationships: All authors have declared that they have no financial relationships at present or within the previous three years with any organizations that might have an interest in the submitted work. Other relationships: All authors have declared that there are no other relationships or activities that could appear to have influenced the submitted work.

\section{References}

1. Aschoff A, Kremer P, Hashemi B, Kunze S: The scientific history of hydrocephalus and its treatment Neurosurg Rev. 1999, 22:67-93. 10.1007/s101430050035

2. Dewan MC, Rattani A, Mekary R, et al.: Global hydrocephalus epidemiology and incidence: systematic review and meta-analysis. J Neurosurg. 2018, 130:1-15. 10.3171/2017.10.JNS17439

3. Lim J, Tang AR, Liles C, et al.: The cost of hydrocephalus: a cost-effectiveness model for evaluating surgical techniques. J Neurosurg Pediatr. 2018, 23:109-118. 10.3171/2018.6.PEDS17654

4. Williams MA, Sharkey P, van Doren D, Thomas G, Rigamonti D: Influence of shunt surgery on healthcare expenditures of elderly fee-for-service Medicare beneficiaries with hydrocephalus. J Neurosurg. 2007, 107:21-28. 10.3171/JNS-07/07/0021

5. Krishnamurthy S, Li J: New concepts in the pathogenesis of hydrocephalus . Transl Pediatr. 2014, 3:185-194. 10.3978/j.issn.2224-4336.2014.07.02

6. Agarwal A, Bathla G, Kanekar S: Imaging of communicating hydrocephalus. Semin Ultrasound CT MRI. 2016, 37:100-108. 10.1053/i.sult.2016.02.007

7. Rekate HL: The definition and classification of hydrocephalus: a personal recommendation to stimulate debate. Cerebrospinal Fluid Res. 2008, 5:2. 10.1186/1743-8454-5-2

8. McAllister JP, Williams MA, Walker ML, et al.: An update on research priorities in hydrocephalus: overview of the third National Institutes of Health-sponsored symposium "Opportunities for Hydrocephalus Research: Pathways to Better Outcomes". J Neurosurg. 2015, 123:1427-1438. 10.3171/2014.12.JNS132352

9. Williams MA, McAllister JP, Walker ML, et al.: Priorities for hydrocephalus research: report from a National Institutes of Health-sponsored workshop. J Neurosurg. 2007, 107:345-357. 10.3171/PED-07/11/345

10. Shaw R, Mahant N, Jacobson E, Owler B: A review of clinical outcomes for gait and other variables in the surgical treatment of idiopathic normal pressure hydrocephalus. Mov Disord Clin Pract. 2016, 3:331-341. 10.1002/mdc3.12335

11. Umscheid CA, Margolis DJ, Grossman CE: Key concepts of clinical trials: a narrative review . Postgrad Med. 2011, 123:194-204. 10.3810/pgm.2011.09.2475

12. Demerdash A, Rocque BG, Johnston J, et al.: Endoscopic third ventriculostomy: a historical review . Br J Neurosurg. 2017, 31:28-32. 10.1080/02688697.2016.1245848

13. Schmitt PI, Jane JA, Jr: A lesson in history: the evolution of endoscopic third ventriculostomy . Neurosurg Focus. 2012, 33:11. 10.3171/2012.6.FOCUS12136

14. Deopujari CE, Karmarkar VS, Shaikh ST: Endoscopic third ventriculostomy: success and failure. J Korean Neurosurg Soc. 2017, 60:306-314. 10.3340/jkns.2017.0202.013

15. Fowler JB, De Jesus O, Mesfin FB: Ventriculoperitoneal Shunt. StatPearls, Treasure Island; 2019. 
16. Yadav YR, Parihar V, Pande S, Namdev H, Agarwal M: Endoscopic third ventriculostomy. J Neurosci Rural Pract. 2012, 3:163-173. 10.4103/0976-3147.98222

17. Ishikawa M: [Idiopathic normal pressure hydrocephalus--overviews and pathogenesis]. Brain Nerve. 2008, 60:211-217. 10.11477/mf.1416100234

18. Williams MA, Malm J: Diagnosis and treatment of idiopathic normal pressure hydrocephalus . Continuum. 2016, 22:579-599. 10.1212/CON.0000000000000305

19. Jeng S, Gupta N, Wrensch M, Zhao S, Wu YW: Prevalence of congenital hydrocephalus in California, 19912000. Pediatr Neurol. 2011, 45:67-71. 10.1016/j.pediatrneurol.2011.03.009

20. Simon TD, Riva-Cambrin J, Srivastava R, Bratton SL, Michael Dean J, Kestle JR, Hydrocephalus Clinical Research Network: Hospital care for children with hydrocephalus in the United States: utilization, charges, comorbidities, and deaths. J Neurosurg Pediatr. 2008, 1:131-137. 10.3171/PED/2008/1/2/131

21. Bech-Azeddine R, Hogh P, Juhler M, Gjerris F, Waldemar G: Idiopathic normal-pressure hydrocephalus: clinical comorbidity correlated with cerebral biopsy findings and outcome of cerebrospinal fluid shunting. J Neurol Neurosurg Psychiatry. 2007, 78:157-161. 10.1136/jnnp.2006.095117

22. Levy LM, Di Chiro G: MR phase imaging and cerebrospinal fluid flow in the head and spine . Neuroradiology. 1990, 32:399-406. 10.1007/BF00588473

23. Behrens A, Eklund A, Elgh E, Smith C, Williams MA, Malm J: A computerized neuropsychological test battery designed for idiopathic normal pressure hydrocephalus. Fluids Barriers CNS. 2014, 11:22. 10.1186/2045-8118-11-22

24. Kulkarni AV, Sgouros S, Constantini S, Investigators I: International infant hydrocephalus study: initial results of a prospective, multicenter comparison of endoscopic third ventriculostomy (ETV) and shunt for infant hydrocephalus. Childs Nerv Syst. 2016, 32:1039-1048. 10.1007/s00381-016-3095-1

25. Beeghly M, Ware J, Soul J, et al.: Neurodevelopmental outcome of fetuses referred for ventriculomegaly . Ultrasound Obstet Gynecol. 2010, 35:405-416. 10.1002/uog.7554

26. Whitehead WE, Riva-Cambrin J, Wellons JC, et al.: No significant improvement in the rate of accurate ventricular catheter location using ultrasound-guided CSF shunt insertion: a prospective, controlled study by the Hydrocephalus Clinical Research Network. J Neurosurg Pediatr. 2013, 12:565-574.

10.3171/2013.9.PEDS1346

27. Keyhole surgery for the positioning of the distal catheter in ventricular peritoneal shunt placement . (2020). Accessed: August 25, 2020: https://ClinicalTrials.gov/show/NCT01739179.

28. Zarin DA, Tse T, Williams RJ, Califf RM, Ide NC: The ClinicalTrials.gov results database: update and key issues. N Engl J Med. 2011, 364:852-860. 10.1056/NEJMsa1012065 